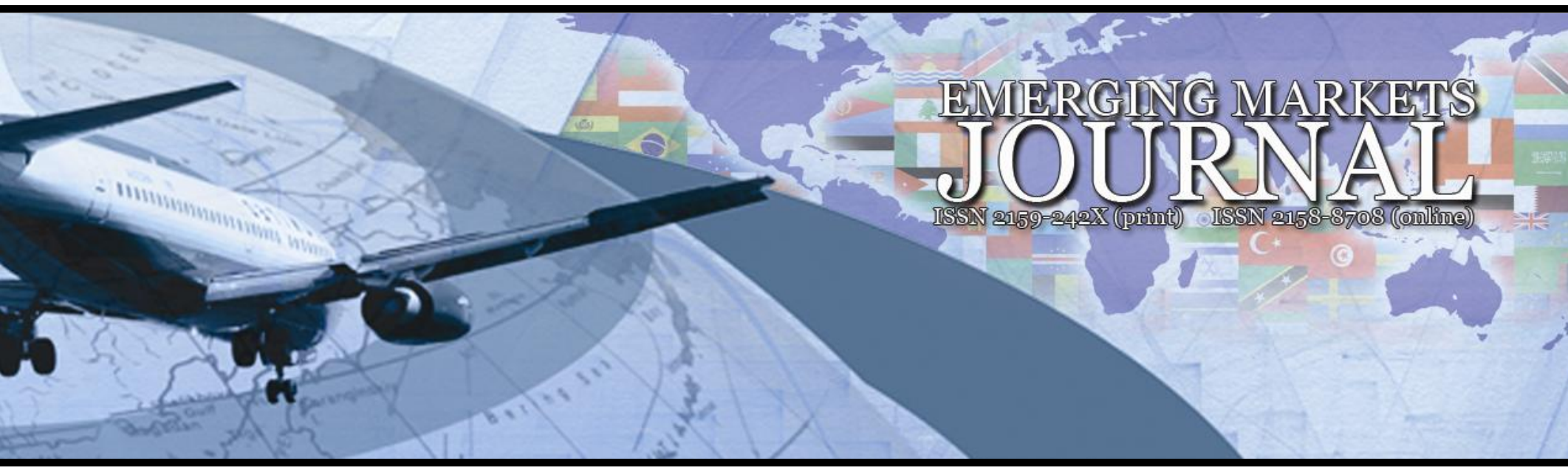

\title{
The Data of Labor Market in Turkey and Time Series Analysis on Economic Growth (2000:01-2013:03)
}

\section{Dr. Bilal Kargı}

Aksaray University | e-mail:bilalkargi@gmail.com

Volume 3 No 3 (2014) ｜ ISSN 2158-8708 (online) | DOI 10.5195/emaj.2014.53 | http://emaj.pitt.edu |

\begin{abstract}
In the present study, labor markets were analyzed, in particular, the reasons of low labor force rate to make sense based on the data of Turkish economy. While in the advanced economies, the labor force rate is quite high and has small fluctuations around a certain extent over a long-term. In the Turkish economy, it prominently falls in a long-term. Turkey is 18th by population size and 17th by GDP in world ranking and although its population effectively provides labor force rate, it will be highly effective on its economic growth. The study that based on co-integration analysis with long-term of the labor data with respect to the economy of Turkey concluded that labor variables concern with GDP and co-integration in a long-term. In particular, when the presence of strong relation between the growth and the non-institutional population is produced, it is emphasized that the present relation between the growth and the labor variable isn't strong enough.
\end{abstract}

Keywords: Population, labor force rate, economic growth.

\section{$(\mathrm{cc}) \mathrm{BY}$}

New articles in this journal are licensed under a Creative Commons Attribution 3.0 United States License.
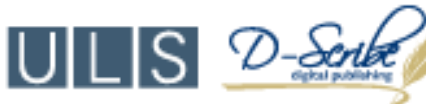

This journal is published by the University Library System of the University of Pittsburgh as part

of its D-Scribe Digital Publishing Program, and is cosponsored by the University of Pittsburgh Press. 
The Data of Labor Market in Turkey and Time Series Analysis on Economic Growth (2000:01-2013:03)

\author{
Dr. Bilal Karg1
}

\section{Introduction}

Even if the relation between population growth and economic growth is a discussed subject in the tradition of the classical economics, it is still the issue that isn't arrived at a consensus at the present time. The discussion base on the result is projected that if the population grows faster than GDP, the economy can't supply with the population. First of all, the discussion that is revived by Malthus (1798) made out the results in direction of population should be a controlled variable. Yet, when the largest world economies are considered at the present time, it will be seen that the largest economies are the countries with the most population. By WB data, the largest 20 economies of the world and their populations is shown on Table 1. Accordingly, 15 countries of the largest 20 economies in the world are also the one of 30 countries with the highest populations in the world.

Turkey is ranked at 17 by its economic growth and at 18 by its population but Turkey is ranked at 5 th by unemployment rate among the largest 20 economies. And, it means that the unemployment rate is quite high but by its population structure. When the data of the labor force rate is examined, it has the lowest rate (with Italy 49\%). In short course, it may be based on that even the economy of Turkey grows, the growth isn't supported enough by the population growth. And even if the population grows, labor force rate is low.
Table 1: GDP \& Population in the world (2012)

\begin{tabular}{|c|c|c|c|c|c|c|}
\hline $\begin{array}{c}\text { The } \\
\text { list of } \\
\text { econo } \\
\text { my }\end{array}$ & $\begin{array}{c}\text { Countr } \\
\mathbf{y}\end{array}$ & GDP & $\begin{array}{c}\text { Popula } \\
\text { tion }\end{array}$ & $\begin{array}{c}\text { The } \\
\text { list of } \\
\text { popu } \\
\text { lation }\end{array}$ & $\begin{array}{c}\text { Unemp } \\
\text { loyment }\end{array}$ & LFP \\
\hline $\mathbf{1}$ & US & 16,244 & 317,626 & 3 & 6,7 & 73,1 \\
\hline $\mathbf{2}$ & China & 8,227 & $\begin{array}{c}1,360,7 \\
20\end{array}$ & 1 & 4,1 & 71 \\
\hline $\mathbf{3}$ & Japan & 5,959 & 127,220 & 10 & 3,9 & 73,9 \\
\hline $\mathbf{4}$ & $\begin{array}{c}\text { German } \\
\text { y }\end{array}$ & 3,428 & 80,586 & 16 & 5,2 & 77,1 \\
\hline $\mathbf{5}$ & France & 2,612 & 65,820 & 21 & 10,8 & 71 \\
\hline $\mathbf{6}$ & UK & 2,471 & 63,705 & 22 & 7,1 & 77,1 \\
\hline $\mathbf{7}$ & Brazil & 2,252 & 201,032 & 5 & 5,4 & 73,1 \\
\hline $\mathbf{8}$ & $\begin{array}{c}\text { Russia } \\
\text { Fed. }\end{array}$ & 2,014 & 143,657 & 9 & 5,2 & 73 \\
\hline $\mathbf{9}$ & Italy & 2,014 & 59,917 & 23 & 12,7 & 64,6 \\
\hline $\mathbf{1 0}$ & India & 1,841 & $1,240,0$ & 2 & 8,5 & 56 \\
\hline $\mathbf{1 1}$ & Canada & 1,821 & 35,295 & 37 & 7,2 & 66 \\
\hline $\mathbf{1 2}$ & $\begin{array}{c}\text { Austra } \\
\text { lia }\end{array}$ & 1,532 & 23,372 & 52 & 5,5 & 65 \\
\hline $\mathbf{1 3}$ & Spain & 1,322 & 46,704 & 28 & 26,7 & 75,1 \\
\hline $\mathbf{1 4}$ & Mexico & 1,178 & 118,395 & 11 & 4,9 & 64,5 \\
\hline $\mathbf{1 5}$ & $\begin{array}{c}\text { Korea } \\
\text { Rep. }\end{array}$ & 1,129 & 50,219 & 26 & 7,5 & 66,4 \\
\hline $\mathbf{1 6}$ & $\begin{array}{c}\text { Indone } \\
\text { sia }\end{array}$ & 0,878 & 249,866 & 4 & 6,1 & 68 \\
\hline $\mathbf{1 7}$ & Turkey & 0,789 & 76,667 & 18 & 9,8 & 54 \\
\hline $\mathbf{1 8}$ & $\begin{array}{c}\text { Nether } \\
\text { lands }\end{array}$ & 0,770 & 16,836 & 63 & 6,9 & 83 \\
\hline $\mathbf{1 9}$ & $\begin{array}{c}\text { Saudi } \\
\text { Arabia }\end{array}$ & 0,711 & 29,994 & 42 & 12,1 & 52 \\
\hline $\mathbf{2 0}$ & $\begin{array}{c}\text { Switzer } \\
\text { land }\end{array}$ & 0,631 & 8,122 & 97 & 3,1 & 68 \\
\hline
\end{tabular}

The most distinct effect on the labor market of Turkey results from the seasonal weight of the agricultural sector. According to TSI, this effect is near to $30 \%$. "In the peak periods of the agricultural activities, because the work force as an unpaid family worker take part in category of uninvolved to labor, labor force rate differ by the periods" (TSI 2012:31). But the data in the analysis, is used by purifying from the effect of season. Also, according to TSI, there are two reasons about the low of labor force rate. The first of these, "generally, the educational level of the population is low. When the educational level is more, the labor force rate is high".

The second is, "the labor force rate of women is low." (TSI 2012:32). In time, the reason of the fall of the labor force rate is based on the agricultural sector. It is said 
that "In 1988, the labor force rate is $57,5 \%$, and in the same year, the share of the agricultural sector from the total employment is $46,5 \%$. In 2006 , labor force rate falls to $48 \%$ by showing the continued downward trend, and the share of the agricultural sector from the total employment falls to $27,32 \%$ " (TSI , 2012:34). It is said that "the place in the business life of the women is limited so, labor force rate is low" by Bagdadioglu (2010). In this study, it emphasized that the relation between unemployment, labor, labor force rate and non-institutional population variables that is the base data of labor market, and growth.

The best discussed and the most frequently referred basic growth -employment and unemployment theories: It can be formed as Classic, Marxist, Keynesian, Neo-classic. Malthus's Law of Population is the most known in the Classical Theory, and it is the efficient approach to the classical theory. Malthus (1798) emphasizes the necessity of population control because of the future imbalance among the arithmetical increase in production of the foodstuff, even the geometrical increase in population. And, in Marxist approach (1976), the limiter of the labor demand is a capital stock. Therefore, the future "request labor" as the basic characteristic of capitalism will apply pressure on the prices. In the end, the rate of surplus value that is confiscated by capitalist will increase. And, it is presented as a natural expectation aimed at labor supply increase in the capitalist system. In Harrod (1948), Domar (1946), Singer as Keynesian approach growth model, it is said that population growth will affect negatively growth. The high population growth will affect negatively the growth process because it will cause the fall of quota per capita disposals. Finally, in Neo-classical Solow (1956) model, while the point in question the causality from the population to growth, the other way round is not valid. So, population growth increase the growth but the growth doesn't cause to increase the population growth. Although these theories that discuss the population as an exogenous variable, in intrinsic growth theories that suggest the growth theory as the intrinsic by concentrating the quality rather than the quantity value of population. The growth process can be supported as the intrinsic by the population with the investments such as education (Romer, 1986; Lucas, 1988), substructure (Grossman and Helpman, 1991) and R\&D (Romer, 1990a; 1990;b).

The indirect relation between unemployment and growth rates is at issue since Okun (1962), and there are many studies (Amezaga, 2012; Arigo, 2001;Benigno, Ricci and Surico, 2010; Lee, 2000; Stock and Ludwig, 2010; Sögner, 2000; Lang and Peretti, 2009) that present the indirectly relation among the two valiables as the empiric. The studies (Uçak, 2013; Yılmaz, 2005; Ceylan and Sahin , 2010; Demirgil, 2010; Alancioglu and Utlu, 2012; Kesici,2010; Günes,2005; Yilmaz,2005; Barisik, Cevik and
Cevik, 2010; Takim, 2010; Muratoglu, 2011) that do about the relation between unemployment and growth in Turkish economy, can present findings relating to entity of the indirectly relation.

\section{Data and Method}

In this study, the data of Turkish economy is used related to 2000:01-2013:03 period. Data got from TCMB-EVDS and TSI. GDP growth data is rate of increase GDP as US dollar. From the variables, Non institutional (POP) and labor (LAB) variables are stated with the number of persons. And, Labor force rate (LFP) and unemployment (UNE) variables that show modulating variation, are variables.

The analysis is formed by two processes. In First process, introductive statistics and correlation relations relating to variables is shown. In second process, the variables are tested whether or co-integrate in a long-term by using time series. Co-integration relation was made by using JohansenJuselius co-integration. The prior condition for this test is to necessary "variables equal to stable". Therefore, principally for series, Dickey-Fuller and Philips-Perron unit root tests are in progress. For these tests;

$$
\rho=\operatorname{Kor}(X, Y)=\frac{\operatorname{Orv}(X, Y)}{\sigma_{x} \sigma_{y}}=\frac{E\left[\left(X-\mu_{x}\right)\left(Y-\mu_{y}\right)\right]}{\sqrt{E\left[\left(X-\mu_{x}\right)^{2}\right] E\left[\left(Y-\mu_{y}\right)^{2}\right]}}
$$

$$
\Delta Y_{t}=\beta_{1}+\beta_{2} t+\beta_{3} Y_{t-1}+\alpha_{i} \sum_{i=1}^{m} \Delta Y_{t-i}+u_{t}
$$

$$
\Delta Y_{t}=\beta_{0}+\beta_{1} Y_{t-1}+\beta_{2} \text { trend }+u_{t}
$$

$$
Y_{t}=\mu+A_{1} Y_{t-1}+\ldots .+A_{p} Y_{t-p}+u_{t}
$$

The equations were used. 1 numbered equation for correlation relation among variables; 2 numbered equation for $\mathrm{ADF}$ unit root test; 3 numbered equation for PP test; 4 numbered equation for JJ tests. All variables were purged from the effect of season because of their quarters. 


\section{Findings}

As the first part of analysis, the introductive statistics were calculated relating to the data and value received was shown in Table -1 .

Table 1: Introductive Statics

\begin{tabular}{|c|c|c|c|c|}
\hline Variable & Average & Std. Error & Median & Max. and Min. \\
\hline GDP & 23,46 & 4,27 & 24,10 & $30,9 / 16,6$ \\
\hline LAB & 24404,9 & 1755,19 & 24030,31 & $28549 / 21933$ \\
\hline UNE & 10,17 & 1,75 & 10,18 & $14,89 / 5,89$ \\
\hline LFP & 48,49 & 1,63 & 48,73 & $51,64 / 45,71$ \\
\hline POP & 50373,55 & 2686,9 & 49916,98 & $55690,68 / 45927,41$ \\
\hline
\end{tabular}

While the labor force rate is $48,49 \%$ since the chosen period 2000:01-2013:03, average unemployment rate was calculated as $10,17 \%$. And, while the non-institutional population is 45,927 in period 2000:01, it increased to 55,690 in period 2013:03.

The acquired correlation coefficients were shown in Table2 by using 1 numbered correlation equation.

Table 2: Correlation Coefficients

\begin{tabular}{|c|c|c|c|c|c|}
\hline Variable & GDP & LAB & UNE & LFP & POP \\
\hline GDP & 1 & 0,684224 & 0,263172 & $-0,02094$ & 0,919314 \\
\hline LAB & 0,684224 & 1 & 0,073315 & 0,660036 & 0,866821 \\
\hline UNE & 0,263172 & 0,073315 & 1 & $-0,37332$ & 0,340008 \\
\hline LFP & $-0,02094$ & 0,660036 & $-3,37332$ & 1 & 0,226582 \\
\hline POP & 0,919314 & 0,866821 & 0,340008 & 0,226582 & 1 \\
\hline
\end{tabular}

Correlation relation among series is shown in Table-2. According to Table-2, the strongest correlation relation is between GDP and non-institutional population variable $(0,919314)$. So, there is a quite strong relation between population growth and GDP. Other strong correlation relation between labor and $\mathrm{KON}(0,866821)$ and then between labor and labor force rate $(0,660036)$.

The results belonging to ADF and PP tests are shown in Table- 3 by using 2 and 3 numbered equations. When the statics ADF compared with the critical values for the semantic level $5 \%$ in brackets, it is seen unit root by the levels of all variables. Yet, the acquired test statics ADF is shown in ADF column by taking difference 1, and when it compared with the critical values in brackets, it is seen that all series become constant. In the present case, it was reached that all series are the result of $I(1)$ as a result of ADF test. Also, it was reached the same results for PP test and was shown that all series are I(1) again.

Table 3: The results of ADF and PP Unit Root Tests

\begin{tabular}{|c|c|c|c|c|}
\hline & ADF & ADF $\Delta$ & PP & PP $\Delta$ \\
\hline \multirow{2}{*}{ GDP } & $\begin{array}{c}-2,812154 \\
(-3,496960)\end{array}$ & $\begin{array}{c}-5,596515 \\
(-3,496960)\end{array}$ & $\begin{array}{c}-2,365321 \\
(-3,495295)\end{array}$ & $\begin{array}{c}-5,596515 \\
(-3,496690)\end{array}$ \\
\hline \multirow{2}{*}{ LAB } & $\begin{array}{c}-1,897907 \\
(-3,495295)\end{array}$ & $\begin{array}{c}-7,705218 \\
(-3,498692)\end{array}$ & $\begin{array}{c}-1,694650 \\
(-3,495295)\end{array}$ & $\begin{array}{c}-18,38391 \\
(-3,496960)\end{array}$ \\
\hline \multirow{2}{*}{ UNE } & $-2,588827$ & $-5,073635$ & $-1,958071$ & $-5,073635$ \\
& $(-3,496960)$ & $(-3,496960)$ & $(-3,495295)$ & $(-3,496960)$ \\
\hline \multirow{2}{*}{ LFP } & $-2,021531$ & $-7,265319$ & $-1,310260$ & $-9,543474$ \\
& $(-3,495295)$ & $(-3,500495)$ & $(-3,495295)$ & $(-3,496960)$ \\
\hline \multirow{2}{*}{ POP } & $-1,362025$ & $-7,070190$ & $-1,447779$ & $-7,070190$ \\
$(-3,176618)$ & $(-3,496960)$ & $(-3,495295)$ & $(-3,496960)$ \\
\hline
\end{tabular}

Prerequisite variables should be the same level constant to do the co-integration test. This condition was provided by doing ADF and PP tests. 4 numbered equations were used for $\mathrm{JJ}$ test and the results were given in Table-4.

Table 4: The Results of Johansen-Juselius (JJ) Cointegration Test

\begin{tabular}{|c|c|c|c|c|c|c|}
\hline Ho & H1 & $\begin{array}{c}\text { Eigen } \\
\text { value }\end{array}$ & $\begin{array}{c}\text { Trace } \\
\text { Stat. }\end{array}$ & $\mathbf{0 , 0 5}$ & $\begin{array}{c}\text { Max- } \\
\text { Eigen } \\
\text { Stat. }\end{array}$ & $\mathbf{0 , 0 5}$ \\
\hline $\mathrm{r}=0$ & $\mathrm{r} \geq 1$ & $\begin{array}{c}0,731 \\
345\end{array}$ & 174,2572 & $\begin{array}{c}88, \\
80380\end{array}$ & $\begin{array}{c}67, \\
03067\end{array}$ & $\begin{array}{c}38, \\
33101\end{array}$ \\
\hline $\mathrm{r}=1$ & $\mathrm{r} \geq 2$ & $\begin{array}{c}0,637 \\
833\end{array}$ & 107,2266 & 63, & 51, & 32, \\
87610 & 79821 & 11832 \\
\hline $\mathrm{r}=2$ & $\mathrm{r} \geq 3$ & $\begin{array}{c}0,427 \\
308\end{array}$ & 55,42837 & $\begin{array}{c}42, \\
91525\end{array}$ & $\begin{array}{c}28, \\
42776\end{array}$ & $\begin{array}{c}25, \\
82321\end{array}$ \\
\hline $\mathrm{r}=3$ & $\mathrm{r} \geq 4$ & 0,263 & 27,00061 & $\begin{array}{c}28, \\
87211\end{array}$ & $\begin{array}{c}15, \\
63201\end{array}$ & $\begin{array}{c}19, \\
38704\end{array}$ \\
\hline
\end{tabular}

When Table- 4 analyzed, there are maximal three vectors that co-integrated variables in a long-term. The default curve was found as 2 based on Akaike and Schwarz Criteria. Co-integrative vector equations obtained like this:

$\partial g d p=0,0042 \partial l b f-3,214 \partial u n e-0,00106 \partial p o p$

The Data of Labor Market in Turkey and Time Series Analysis on Economic Growth (2000:01-2013:03) 
According to 5 numbered equation, 1 unity rise in labor increases GDP as 0,004 in a long-term. 1 unity rise in unemployment cause to fall of GDP as 3,214, and 1 unity rise in population cause to fall of GDP as 0,00106 .

\section{Conclusion}

The economy of Turkey (1987-2012 average $4,22 \%$ ) that has the high growth rates, also has the high population growth rate $(2,1 \%)$. Yet, unemployment rate is also quite high as average 8,52 inter annual 19872012.Although, the labor force rate in OECD countries is $70,93 \%$ since 2012 , it seen that the labor force rate is very low in Turkey. The labor force rate should be increased to accelerate the growth. Therefore, the first suggestible aim is to increase the number of women to the working population. And, the growth rate will be supported with the variables cointegrate in a long term and with the politics based on increasing employment. In particular, the fall in GDP after the unemployment increased, and if the unemployment issue is solved in the economy of Turkey (at least, fall to the natural unemployment level), it is shown that may be accessed to the high growth potential.

\section{References}

Alancioglu, A. and Utlu, S., (2012). "Employment and Economic Growth: The Case of Turkey". KSU Journal of Social Sciences, 9(2), 189-206.

Arico, F. R., (2001). "Growth and Unemployment: Twards a Theoretical Integration". Journal of Economic Survey, 17(3), 419-455.

Barisik, S., Cevik, E. and Cevik, N., (2010). "Okun's Law, Asymmetry Relationship and Jobless Growth in Turkey: Markov-Switching Approach". Maliye Dergisi, 159, 88-102.

Benigno, P., Ricci, L. A. and Surico, P., (2010). "Unemployment and Productivity in the Long Run: The Role of Macroeconomic Volatility". IMF Working Paper, No.259.

Ceylan, S. and Sahin, B. Y., (2010). "Asymmetry in the Erlationship Between Unemployment and Economic Growth". Dogus University Journal, 11(2), 157-165.

Demirgil, H., (2010). “Okun Yasasi’nin Turkiye icin Gecerliligine Dair Ampirik Bir Calisma". Alanya Isletme Fakultesi Dergisi, 2(2), 142-155.

Domar, E. D., (1946). "Capital Expansion, Rate of Growth and Employment". Econometrica, 14(2), 137147.

Grossman, G.M., Helpman, E., (1991). Innovation and Growth in the Global Economy. MIT Press, Cambridge, Mass.
Gunes, S., (2005). "Population and Economic Growth Relationship in Turkey: An Econometric Analysis". AU., SBF Dergisi, 60(3), 123-136.

Harrod, R. F. (1948). Toeards a Dynamic Economics. Macmillan, London.

Kesici, M. R., (2010). "In High Growth Phase of Turkey Economy Employment and Unemployment". IsGuc Industrial Relations and Human Resources Journal, 12(3), 7-26.

Lang, D. and Peretti, C., (2009). "A Strong Hysteretic Model for Okun's Law: Theory and Preliminary Investigation". International Review of Applied Economics, 23(4), 445-462.

Lee, J., (2000). “The Robustness of Okun's Law. Evidence from OECD Countries". Journal of Macroeconomics, 22(2), 331-356.

Lucas, R. E. J., (1988). "On the Mechanics of Economic Development". Journal of Monetary Economics, $22,3-42$.

Malthus, T. (1798). An Essay on the Principle of Population. (http://www.esp.org).

Marks, K. ve Engels, F., (1976). Nufus Uzerine. Sol Yayinlari, (Çev. M. Erdost).

Muratoglu, Y., (2011). "The Relationship Between Growth and employment: The Case of Turkey". International Conference on Eurasian Economies.

Okun, A. M. (1962). "Potential GNP: Its measurement and significance". Proceedings of the Business and Economics Statistics Section of the American Statistical Association. 98-104.

Romer, P. M., (1986). "Increasing Returns and Long-Run Growth". Journal of Political Economy, 94(5), 1002-1037.

Romer, P.M. (1990a). "Capital, Labor, and Productivity". Brooking Papers on Economic Activity, Microeconomics, (Edt.) M. N. Baily and C. Winston, The Brooking Institution, 337-367.

Romer, P. M. (1990b). "Endogenous Technological Change". Journal of Political Economy, 98(5), 71-101.

Singer, H. W. (1952). "The Mechanics of Economic Development", reprinte in International Development: Growth and Change. McGraw-Hill.

Sogner, L. and Stiassny, A., (2000). "A CrossCountry Study On Okun's Law", Vienna University of Economics and Business Administration Working Paper, No. 13.

Takim, A., (2010). "The Relation Between Economic Growth and Unemployment in Turkey: Granger Causality Test”. DPU Sosyal Bilimler Dergisi, 27, 315-324.

Ucak, A., (2013). "The Growth Dynamics of the Turkish Economy and Its Impact on the Unemployment". International Journal of Human Sciences, 10(1), 202-223. 
Yilmaz, O., (2005). "Turkiye Ekonomisinde

Buyume ile Issizlik Oranlari Arasindaki Nedensellik

Iliskisi". Ekonometri ve Istatistik Dergisi, 2, 11-29. 